\title{
近世期の信達地方阿武䀼川沿いに設けられた郷蔵関連施設の空間構成に関する研究 SPATIAL STRUCTURES OF FACILITIES CONCERNING GOGURA THAT LOCATED ALONG THE ABUKUMA RIVER IN THE SHINTATSU REGION IN THE EDO PERIOD
}

\author{
相 模 誓 雄*1
}

\section{Chikao SAGAMI}

\begin{abstract}
This study draws attention to facilities concerning the gogura that were located along the Abukuma River in the Shintatsu region for the shipping of jomai to Edo. It aims to clarify the fact of their spatial structures based on valuable illustrations, mura-meisai-tyo (details of a village), and other historical sources. Yose-gura and tome-ya in the Shintatsu region during the Mid-Edo period were at the heart of a system where villages worked together to transport jomai, a practice that continued in the gogura-syo during the last days of the Tokugawa Shogunate.
\end{abstract}

\section{Keywords : Storehouse, Premises, Spatial structure}

蔵, 屋敷, 空間構成

\section{1.はじめに}

阿武隈川流域の旧信夫郡之旧伊達郡（「信達地方」と呼ばれる） (Fig. 1) は、幕藩体制成立時、米沢藩領であったが、寛文 4 年 (1664) に幕府領になった注 1$)$ 。寛文 10 年 (1670)、幕府は、江戸の商人の河 村瑞賢に信夫郡の年貢米（「城米」と呼ばれる）を江戸へ廻漕するよ うに命じ注 2)、翌年に東廻航路が開かれた注3)。阿武德川沿いには河 岸が設けられ、その数は、宝暦 8 年（1758）において福島城下、桑 折村、東大枝村など 14 ヶ所に及んだ注 4$)$ 。幕府領における城米輸送 には、農民が深く関わっていた。村々には、村の責任者が領主に代 わって徴収する年貢米を納める郷蔵が存在した注 5)。通常郷蔵は村毎 に設けられるが、当地では、複数の村が「蔵組」をつくり、各村の 郷蔵を 1 ケ所にまとめて設けた。「寄蔵」と呼ばれる。寄蔵に収めら れた米は、城米として近くの河岸へ運ばれて船で積み出される(「津 出し」と呼ばれる)。寄蔵を河岸の周辺に設けられない村々は、河岸 に城米を留め置くため「留屋」を設けた。留屋は、寄蔵から幕府の 御蔵への米の輸送を中継する施設と言える。同じ河岸を利用する 村々は、「河岸組」を編成し、共同して津出しや迴漕に関わる業務を 行った。このような留屋もその規模から蔵所の観を呈していたと予 想される。天明期（1781-1788）頃になると、村毎に城米を直接河岸 へ運んで津出するようになったと史料に記されている注 6 )。藩政後期 の信達地方に関する史料には、寄蔵や留屋といった呼称は見られな くなる。阿武隈川沿いには、「郷蔵」、「御城米御蔵」や「川岸御蔵」 と呼ばれる蔵所が存在したが (Table1)、その役割は、藩政中期の寄 蔵や留屋と変わりなかった。

寄蔵や留屋の建築遺構は後述する 1 棟のみであり、蔵所の実態が 知られる図面も少ない。本研究は、寄蔵や留屋など信達地方の阿武

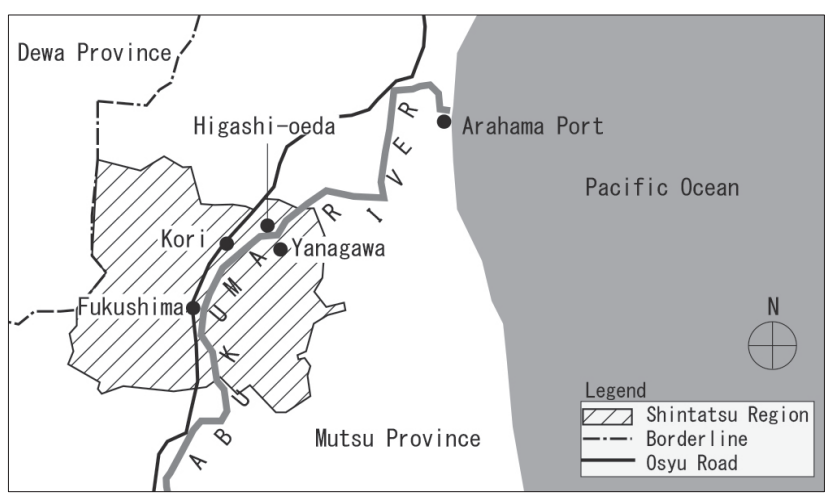

Fig. 1 The Shintatsu Region on the Abukuma River Basin

隈川沿いにおける郷蔵関連施設に焦点を当て、貴重な絵図や村明細 帳といった史料から、それらの空間構成の実態を明らかにすること を目的とする。

\section{2. 既往研究 · 手順}

信達地方の阿武隈川沿いにおける郷蔵関連施設に関する既往研究 には、組織から施設までを包括的に述べた安田初雄 ${ }^{9)}$ や竹川重男注 7)による史学の研究が見られる。郷蔵建築に関しては、富山博が全 国各地の建築遺構を調查している。その一環で阿武隈山地の郷蔵を 報告しているが ${ }^{11)}$ 、信達地方は含まれてない。筆者は、幕府や諸藩 が年貢米の徴収及び廻米のために設けた御蔵所の空間構成について

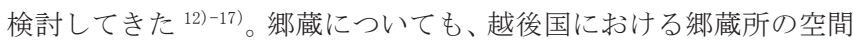
構成について検討した ${ }^{18)}$ 。安田や竹川の研究と同じく、本研究も信 達地方における郷蔵関連施設に焦点を当てるが、それらの空間構成 
を検討しようとするものである。

藩政期の当地における河岸の周辺には、郷蔵関連施設があったが、 史料から存在が知られるものは、信夫郡の渡利村（天神河岸と渡利 河岸の 2 个所)、福島城下、瀬上村、伊達郡の伏黒村、桑折村、中瀬 村、徳江村、東大枝村、梁川村の 10 ケ所である（Table1）。なお、 上郡河岸の蔵所は、幕府の御蔵所であり、出羽国置賜郡の城米の津 出しに用いられたので注8)、本稿では取り上げない。上記のうち、桑 折村の寄蔵や幕末期の東大枝村の郷蔵所は、蔵が村毎に建てられた。 一方、河岸組が設けた留屋の様子は上記とは異なった。

以上のことから本稿は、はじめに、各施設の成り立ちや建物概要 を示す。次に、河岸の施設と郷蔵に分けてそれぞれの共通性及び空 間構成手法を明らかにする。終わりに、信達地方阿武隈川沿いにお ける郷蔵関連施設の空間構成の意義についての考察を試みることに する。

\section{3. 成り立ち・建物概要}

\section{3,1 信夫郡}

\section{1.1 渡利村}

渡利村においては、天神河岸と渡利河岸に郷蔵関連施設があった。 天神河岸には、小手郷 4 ケ村の留屋があった。元禄・宝永期 (16881710）頃の「小手郷村々書上帳」の立子山村の項注 9) に、「天神川岸 一、長武十武間武間半はり 内訳 一、六間立子山村 一、六間飯 野村 一、五間大窪村 一、五間青木」とある (Fig. 3, 2-5)。内訳 に記される各村の長さを合計すると 22 間になるので、梁行 2.5 間 の一棟を 4 ケ村で分けて共有していた可能性がある。一方、文化 11 年（1814）の「立子山村明細書上帳」注 10) に、「一天神川岸御蔵桁六 間横三間壱ヶ所 右御蔵年々御廻米川下ケ仕候二付 右川岸江御上 米運送御改を請申候上 川下ケ之間納置候御蔵二御座候」とあり、 藩政後期になると立子山村が単独で「川岸御蔵」を設けている。前 記史料の留屋の立子山村部分と比較すると、梁行が異なるが、桁行 は同じであり、用途は留屋とほぼ同じであった。

渡利河岸には、小手郷 14 ケ村の留屋や、渡利村と大笹生村の寄 蔵があった。元禄 16 年 (1703) の「信夫郡渡利村差出シ帳」注 11)に、 「一同 (小手寄蔵) 長六十六間 横武間半 高八尺五寸 右同断 (萱 ふき）下 屋敷三反三畧十八歩除地 土蔵（中略）一寄御蔵 長 八間 横三間、高九尺 渡利村大笹生村」とある。また、前掲元禄・ 宝永期 (1688-1710) 頃の「小手郷村々書上帳」の秋山村の項注 ${ }^{12)} に 、$

「一、長五拾六間 横拾八間 屋敷 三反三㽞拾八歩 渡利村川岸 一、留屋 長六拾式間 武間半ばり (後略)」とあり、前者の長さ 66 間の小手寄蔵は、後者の長さ 62 間の留屋に対応すると見られる。呼 称の違いは、施設が立地する村から見ると寄蔵であり、それ以外の 河岸組の村々から見れば留屋といった視点の違いによるものと推察 される注 ${ }^{13)}$ 。なお、このことは、後述する瀬上村でも同じである。本 稿では、河岸組の村々（Fig. 3,6-18）の留屋として検討を進める。 後者の史料に小手郷の 14 个村と「納米入」にそれぞれの長さが併 記されている。長さを合計すると 62 間になる。長さは桁行と見るこ とができるが、敷地長さ 56 間、横 18 間の屋敷地に、桁行 62 間の直 屋は収まらない。このことは後で検討する。収納空間は、最小規模 の村で 5 坪、最大規模の村で 15 坪となり、 7.5 坪の村が最も多い。 渡利村と大笹生村の寄蔵も、後者から見れば留屋であろう。村毎
Table1 A list of facilities concerning Gogura on the Abukuma River in the Edo period

\begin{tabular}{|c|c|c|c|c|c|}
\hline \multirow{2}{*}{ County } & \multirow{2}{*}{ Village } & \multirow[t]{2}{*}{ Riverport } & \multicolumn{2}{|c|}{$\begin{array}{l}\text { Early Edo period, } \\
\text { mid-Edo Period }\end{array}$} & \multirow{2}{*}{$\begin{array}{l}\text { Late Edo period } \\
\text { Others }\end{array}$} \\
\hline & & & Yose-gura & Tome-ya & \\
\hline \multirow{5}{*}{ Shinobu } & \multirow{3}{*}{ Watari } & Tenjin & & 0 & Kawagishi-okura \\
\hline & & Watari & $\bigcirc$ & O & \\
\hline & & Fukushima & O & & \\
\hline & Motouchi & & & & \\
\hline & Senoue & & & $\bigcirc$ & \\
\hline \multirow{9}{*}{ Date } & Oka & & & & \\
\hline & Fushiguro & & $* 1$ & 0 & \\
\hline & Kori & & $\mathrm{O}$ & & Gogura*2 \\
\hline & Kamigori & & $* 3$ & & \\
\hline & Nakaze & & & 0 & \\
\hline & Danzaki & & & & \\
\hline & Tokue & & 0 & & \\
\hline & Higashioeda & & $\mathrm{O}$ & & Gogura, Kashi-okura*4 \\
\hline & Yanagawa & & 0 & 0 & Kawagishi-okura \\
\hline
\end{tabular}

Note)*1:A relic of Yose-gura in Fushiguro District Date City *2: 文久元年（1861）「小坂村明細帳」（文献 23）, pp. 339-341 所収 *3:0kura-syo owned by Yonezawa Domain

*4: 文久元年（1861）「西大窪村指出明細帳」（文献 23）, pp. 331-336 所収）

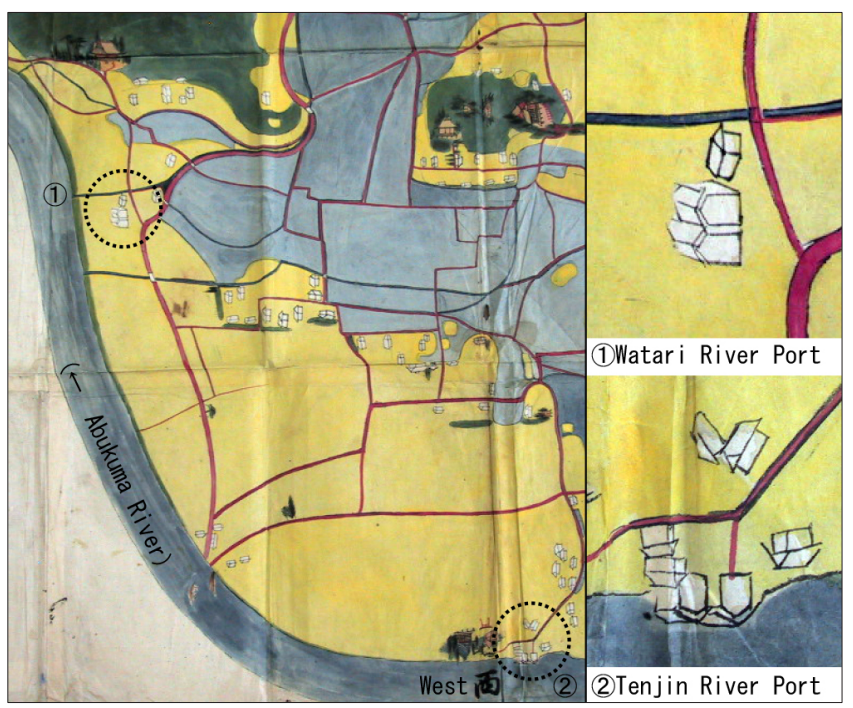

Fig. 2 A painting of Watari Village in the year 1836

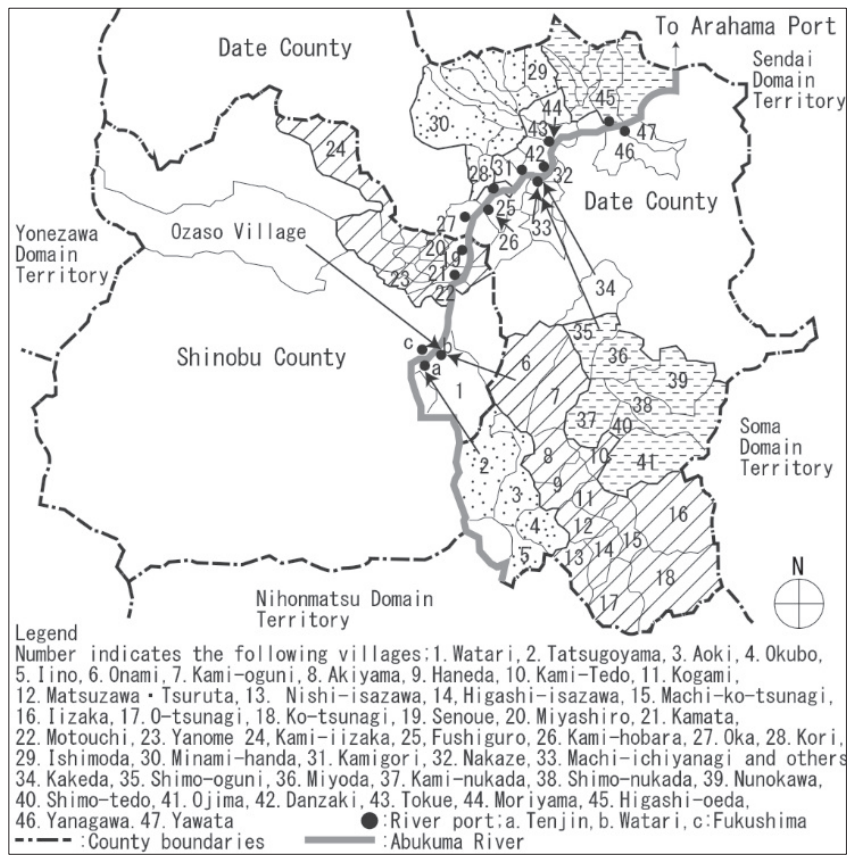

Fig. 3 Location of the river port and the villages 
に分けた場合、平均坪数は 12 坪であり、上記の平均的な 7.5 坪より 広い。大笹生村は、渡利村から見て対岸、阿武隈川と平野部で隔た れた山村であり (Fig. 3)、渡利村と蔵組をなした経緯は不明である。

これらの施設を天保 7 年（1836）の「渡利村絵図」（Fig. 2）にお いて見ると、天神河岸、渡利河岸それぞれに妻側を川へ向けた蔵が 2 棟描かれている。同年の別の村絵図注 ${ }^{14)}$ には前者に「御蔵」(前述 の川岸御蔵)、後者に「御米蔵」と記されている。他に郷蔵が描かれ る絵図は見られない。

\section{1.2 福島城下}

福島河岸には、米沢藩の御蔵所や福島城主の蔵屋敷があった。享 保 20 年 (1735) の「福島城下惣町絵図」注 15) には、宝林寺から下流 一向かって、「大工棟梁治郎兵衛」「寄御蔵」(2 ヶ所)、「畑」、米沢 米積場」と記される屋敷地などが描かれている。明和期 (1764-1771) の「阿武隈川舟運図」や文政期（1818-1829）の「阿武隈川水路図」 注 16) には、宝林寺から下流へ向かって、「上杉弾正大唱蔵」、「上総屋 船会所」、「御城米御蔵」、「板倉甲斐守（福島城主）蔵」と記される 屋敷地が描かれている。享保 20 年（1735）の「福島城下吻町絵図」 に「寄御蔵」と記される敷地と「阿武隈川水路図」に「御城米御蔵」 と記される敷地は、同一とは見られない。なお、これらの図に建物 は描かれていない。他に蔵所が描かれる絵図は見られない。

\section{1 .3 瀬上村}

享保 17 年 (1732) の「瀬上村絵図」注 17) には、阿武隈川左岸、川 岸からやや離れた土地に、柵で囲まれた 3 棟の建物が描かれており、

「寄御蔵」と記されている。一方、寛保 3 年（1743）の「上飯坂村 明細帳」注 ${ }^{18)}$ には、1 7 ケ村による河岸組の留屋と記されている。 呼称の違いについては前述した。

河岸組の村は、後述の瀬上村をはじめ鎌田村など阿武隈川左岸の 村々であった (Fig. 3, 19-24)。延享 3 年 (1746) の「瀬上村明細帳」 注 19) には、「一郷蔵敷壱ヶ所是者前々より之蔵組御料宮代村入 江野村井野目村鎌田村本内村瀨上村 川又御料高梨村沖中野村平田 村飯塚村佐場ノ北矢ノ目村南矢ノ目村丸子村 松平越中守様御料知 上飯坂村并下飯坂村 $\propto$ 拾六ヶ村二而相納申候 雨屋破損之節八御 材木被下置御普請被仰付候」とある。この「雨屋」は、雨露をしの ぐ程度の簡易な構造の小屋や、土蔵を雨から守る覆屋などが考えら れる。筆者は、福島市において過去に土蔵の覆屋を見たことがない ので注 20)、小屋の可能性が高い。また、前掲の「瀬上村明細帳」か ら、この留屋には、「御料 (幕府直轄)」、「川又御料（川俣代官所支 配)」、「松平越中守様御料知（桑折藩・譜代大名）」といった所轄や 領主の異なる村々の米が保管されていたことが知られる。従って、 享保 17 年（1732）の「瀬上村絵図」に描かれる 3 棟の蔵は、所轄・ 領主別に設けられた留屋と考えられる。

しかし、宝暦 7 年（1757）頃に本内（鎌田）河岸が開設されると、 瀬上河岸組から 5 ヶ村が抜け、安永 4 年（1775）にはさらに 8 ヶ村 が抜けており注21)、留屋は消滅したと推察される。

\section{2 伊達郡}

\section{2.1 伏黒村}

伏黒河岸は、阿武隈川右岸にあった。寛保 2 年（1742）に白河藩 領になった上保原村の場合、幕府領時代から伏黒村の河原に留屋を 設けていた。寛保 2 年（1742）の「上保原村鑑指上帳」注22)に、「一 御年貢米津出 是者岡御料伏黒村川原之内留屋作り置、右留屋へ持

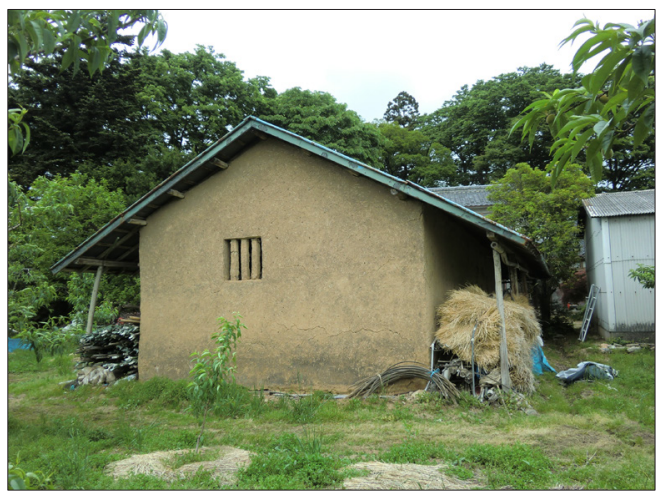

Fig. 4 0ld mud-walled storehouse in Fushiguro District Date City which was one of Gogura in Yose-gura

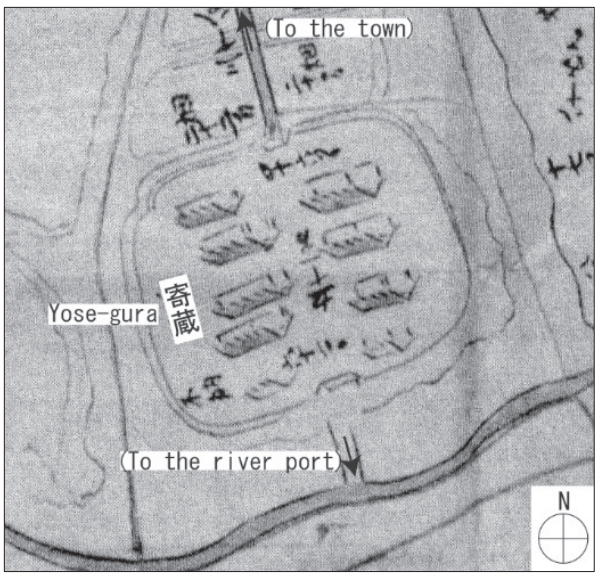

Fig. 5 Yose-gura in the Kori Village from a drawing of Kor $\mathrm{i}$ Town around the mid-Edo period

参仕御改申請上納仕来り申候」とある。当地は、領地替えが行われ た地域であり、河岸組の村々は明らかでない。なお、私領（藩）へ 転入後もこの河岸を用いていた村が知られる注23)。

現在の伊達市伏黒字川岸地区には、藩政期の寄蔵と伝えられる 1 棟の土蔵（伊達市指定有形文化財「伏黒河岸寄蔵」））が残されてい るが注 24)（Fig. 4）、この遺構は屋敷地にあり、河原の内ではない。規 模は、桁行 5 間、梁行 2 間半であり、1 1 村分の大きさである。こ の郷蔵の位置や建物が描かれる絵図史料は見られない。

\section{2.2 桑折村}

郷蔵は、奥州道中の桑折宿とともに台地上に設けられたので、河 岸まで 6 町余の距離があった。この蔵地は、米沢藩領時代、藩の御 蔵所であった淓 25$)$ 。寛文 4 年 (1664)、幕府領になり、寄蔵になった と推測される。元禄 6 年（1693）に米沢藩時代以来の御蔵守の居宅 が建てられている注 26)。当地は、元禄 13 年 (1700) から延享 4 年 （1747）まで桑折藩（譜代大名）領となる。桑折藩領時代の作と思 われる「奥州桑折之図」(Fig. 5) の蔵地に「寄蔵」と記されており、 寄蔵は継承されていた注 27$)$ 。寄蔵に描かれる 9 棟の建物のうち、河 岸側の比較的小規模な 2 棟は御蔵守関係、町場側の 7 棟は郷蔵と見 られる注 28)。幕府領時代の明和 9 年 (1772) の「桑折村明細帳」注29) に、「一、郷蔵 此町歩壱町廿四歩 壱ヶ所 但御置米郷蔵壱ヶ所 村々郷蔵九ヶ所」とあり、蔵組は南半田村注30) など 9 ケ村であった (Fig. 3, 28-30)。以上のことから Fig. 5 の寄蔵の蔵々の多くは、村 毎に建てられていたと考えられる。蔵々は、町場側と河岸側に開か 
れた門を結ぶ庭の両側に、妻側を向けて建ち並んでいる注 31 。村毎 の米の搬入・搬出に配慮された建物配置と言えよう。

寛政 4 年 (1792)、置粐御蔵が設けられた注 ${ }^{32)}$ 。寛政末・享和始 （1800-1801）の蔵組は１０ケ村であり注33)、藩政後期においても寄 蔵の形式は存続したと推測される。なお、桑折河岸における留屋の 存在は知られない。

\section{2.3 中瀬村}

中瀬河岸にも小手郷村々の留屋があった。元禄・宝永期 (1688-1710) 頃の「小手郷村々書上帳」の御代田村の項注 ${ }^{34)}$ に、「中瀬村中瀬留屋 一通法四里程 一、留屋式拾六間三間はり 内訳一、三間御代田一、 三間下ぬかた 一、五間上糠田 一、三間下小国 一、四間布川 一、 三間下手戸一、五間小嶋 一、(ママ)」とある（Fig. 3, 35-41）。 また、寛保 2 年 (1742) の「町市柳村鑑指上帳」注 35$)$ にも、「一御年 貢津出 是八梁川御料中瀬河岸之内留屋作置、御改申請上納仕来り」 とあり、白河藩領になった町市柳村もまた、幕府領時代からこの留 屋を利用していたと推測される。明治 2 年（1869）写しの「懸田村 明細書上帳写」注 ${ }^{36)}$ には、「一御年貢津留 是八瀬の上領中瀬村一小 屋建置、村方二て御年貢米斗立同所一持運び御改を受、其より阿武 隈川江河脊出仕、(後略)」とあり、小屋であった。中瀬留屋が描か れた絵図史料は見られない。

\section{2.4 徳江村}

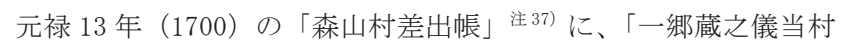
二八無御座候、只今迄八徳江村之寄蔵江入置尤番人付置申候、」とあ り、当時、徳江村に寄蔵があった (Fig. 3, 43, 44)。その実態は明ら かでない。なお、元禄 13 年 (1700) から延享 4 年（1747 年）まで、 森山村は桑折藩領であった。

\section{2.5 東大枝村}

東大枝村注 38 ）(現在の伊達市梁川町東大枝, Fig. 3, 45) の郷蔵所は、 後述するように、伊達郡における城米輸送の重要な拠点の 1 つであ った。貞享 5 年 (1688) の「東大枝村寄御蔵場書上申事」注 39 ) から 寄蔵の存在が知られる。天明 9 年（1789）の「伊達郡東大枝村明細 差出し帳」注 40) に、「一当村郷蔵之儀寄蔵江西大枝貝田東大窪西大窪 只今二而八五十沢光明寺六ヶ村二而御城米納申候、尤番人扶持米之 儀者右蔵組二而壱人扶持相出申候、」とあり、東大枝村と 6 ケ村によ る蔵組の寄蔵であった。文化 9 年（1812）の「五十沢・東大枝村境 絵図」注 ${ }^{41)}$ や天保 8 年 (1837) の「奥州伊達郡東大枝村絵図」(Fig. 6) を見ると、阿武隈川左岸の段丘上に「郷蔵」と記される蔵所が描か れている。蔵は、前者に 3 棟、後者に 5 棟描かれている。時代が下 るにつれて蔵の数が多くなっている。しかし、これらの図は、その 目的から蔵の数を正確に描いたものとは言い難い。河岸とは、「御出 道」で直接結ばれており、その距離は 6 町であった。この郷蔵所は、 明治維新後も存続していたが、明治 9 年 (1876) に蔵が解体され注 42)、明治 22 年 (1889) に土地が払い下げられた注 ${ }^{43)}$ 。

明治 9 年 (1876) の郷蔵所の見取図（Fig. 7) があるので、蔵々に ついて詳しく見たい。本図から幕末期の郷蔵所を見ても大過ないだ ろう。まず、本図には、「東大枝御蔵」と記される御蔵が 1 棟描かれ ている。前掲の天明 9 年 (1789) の「伊達郡東大枝村明細差出し帳」 に、「一御置犊之儀者東大枝村貝田東大窪石母田山崎泉田藤田伊達崎 徳江右拾ヶ村御年貢御置粐納申候、(後略)」とある。御蔵とあるこ とから、この蔵は領主（幕府）の蔵であり、東大枝村の年貢米とそ

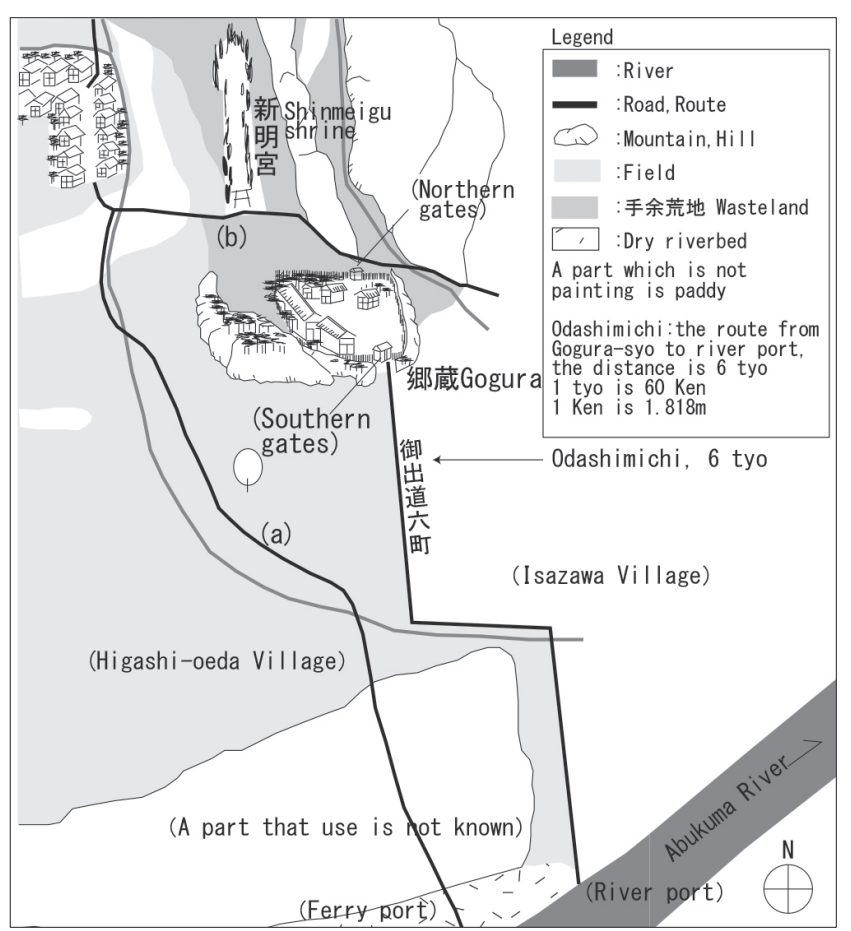

Fig. 6 Vicinity of Gogura-syo in the Higashi-oeda Village from a painting of the Higashi-oeda Village in the year 1837

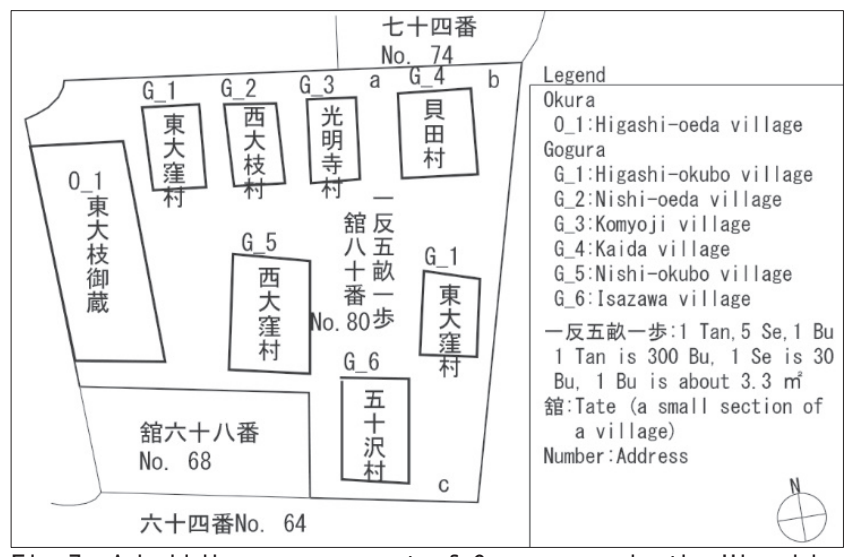

Fig. 7 A building arrangement of Gogura-syo in the Higashioeda Village in the last days of the Tokugawa Shogunate

の周辺の村々の囲粐を納めるため、藩政中期以降に設置されたと推 察される注 44)。村数は 12 であり、蔵組以外の村が含まれている。 次に、蔵組の村名が記される建物が 7 棟描かれている。これらは村 毎に建てられた郷蔵と見られる注 ${ }^{45)}$ 。但し、東大窪村の蔵は、2 棟 である。本村は、天保 8 年 (1837) に「新料」、「古料」や「上知」 に分割されていた注 46$)$ 。明治 4 年（1871）に上知が併合されている ので注 47)、一方は新料、もう一方は古料の蔵と考えられる。天保 8 年 （1837）の「奥州伊達郡東大枝村絵図」の郷蔵所の周囲は、柵で囲 まれ、北端と南端に門が開かれている。明治 9 年（1876）の「地積 改正野取図面」（Fig. 7) において門の位置を検討する。Fig. 6 にお いて北門は、敷地北辺の中央よりやや東寄りに描かれている。しか し、本図は郷蔵所を正確に描いたものとは言い難い。Fig. 7 では貝 田村の蔵の東西両側の空地が、西大枝村の蔵と光明寺村の蔵との間

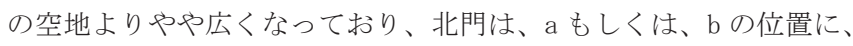
南門は、「五十沢村」と記される建物の東側の空地に面した場所 c に 
開かれていたと推測される。このように東大枝村の郷蔵所において も、桑折村の寄蔵のように河岸側とその反対側に門が開かれるが、 郷蔵の配置は規則的でなかった。

以上、幕末期の郷蔵所は、蔵が村毎に棟を分けて設けられていた が、時代的変遷については今後の検討を要する。

\section{2.6 梁川村}

梁川村には、梁川村など下郷と呼ばれる村々の年貢米を納める寄 蔵があった (Fig. 3, 46)。享保 16 年 (1731) の「梁川村指出書上帳」 注 48) によると、その敷地は、長さ 33 間半、横 19 間半であった。そ の場所は明らかでないが、阿武隈川の河岸から 7 町離れていた注49)。 なお、作製年不明の「梁川古城図」注 50) を見ると、梁川町の北側を 阿武隈川へ向かって流れる塩野川沿いに、「米蔵」と記されており、 寄蔵の可能性が高い。寄蔵は河岸から離れていたので、河岸に「留 小屋」を設けて船で積み出される城米の留め置き場とした。前掲の 享保 16 年 (1731) の「梁川村指出書上帳」に、「(前略) 御年貢米津 出之節御米入置申留小屋修復等入用之竹木八御立林二而被下葍縄人 足八下郷村々二而御米高二割合年々相勤申候、(後略)」とある。寄 蔵や留小屋の実態が知られる史料は見られない。

\section{4. 考察}

\section{1 河岸の施設}

\section{1.1 共通性}

藩政中期の阿武隈川右岸における渡利村の天神河岸と渡利河岸、 中瀬村の留屋の実態が知られた。これらに共通する点は、第一に、 村々の梁行が同じであること、第二に、桁行は村によって異なるこ とである。その長さは、最短が 2 間、最長が 6 間である。

\section{1.2 空間構成手法}

まず、渡利河岸の留屋を、同じ時代に河岸組 14 ケ村のうち 11 ヶ村が秋山村に設けた寄蔵と比較する。元禄・宝永期 (1688-1710) 頃の「小手郷村々書上帳」の秋山村の項注 ${ }^{51)}$ に、「一、寄御蔵四ヶ所 （中略）三間二廿一間壱ヶ所 三間十武間壱ヶ所 三間十一間壱ヶ 所 三間七間壱ヶ所 是八只今無御座候」とあり、寄蔵は 4 棟を 1 1 ケ村が共有していた。桁行の合計は 51 間であり、1 ケ村当り平均 は 4.6 間となる。一方、留屋の 1 ヶ村当り桁行の平均は、前掲注 12) より 3.4 間となり、桁行梁行とも留屋の方が短い。このような小さ な留屋を村毎に建てると、両妻側の外壁や軒が余計に必要になるの で効率が悪い。従って、各村の空間を可能な限りまとめた方がいい だろう。また、留屋の普請用の竹木は幕府から支給されたが、人足 やその他の資材は村々が米高の割合で供出しており注 52)、村々は共 同して普請に当たる必要があった。

次に、棟数について検討する。前掲の「小手郷村々書上帳」には、 渡利河岸の留屋について長さ 62 間とあり、この桁行の直屋では、敷 地に収まらないことを前述した。しかし、Fig. 8 にように曲屋とす れば納まる。なお、筆者が過去の研究で取り上げた幕府や諸藩の御 米蔵で最長のものは、九州地方における柳川藩の三の丸御蔵所の御 米蔵で、桁行 85 間、梁行 3 間であり注53)、前記の長さは留屋でも実 現可能であろう。また、複数棟でも成り立つ。他の河岸組の留屋を 一棟とした場合の間取りをFig. 8 に示す。

所轄毎に棟を分けていたと考えられた阿武隈川左岸の瀬上村の留 屋も上記の留屋と同じ空間構成となる。以上のことから留屋は、地

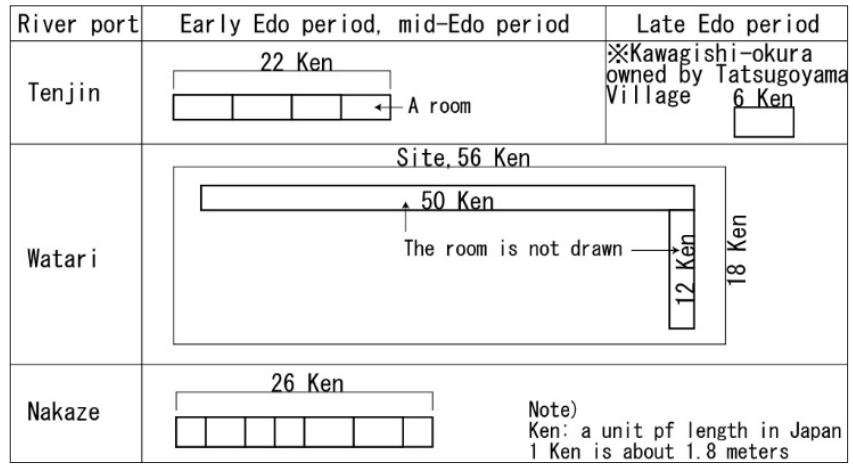

Fig. 8 Schematic diagrams that restored the Tome-ya

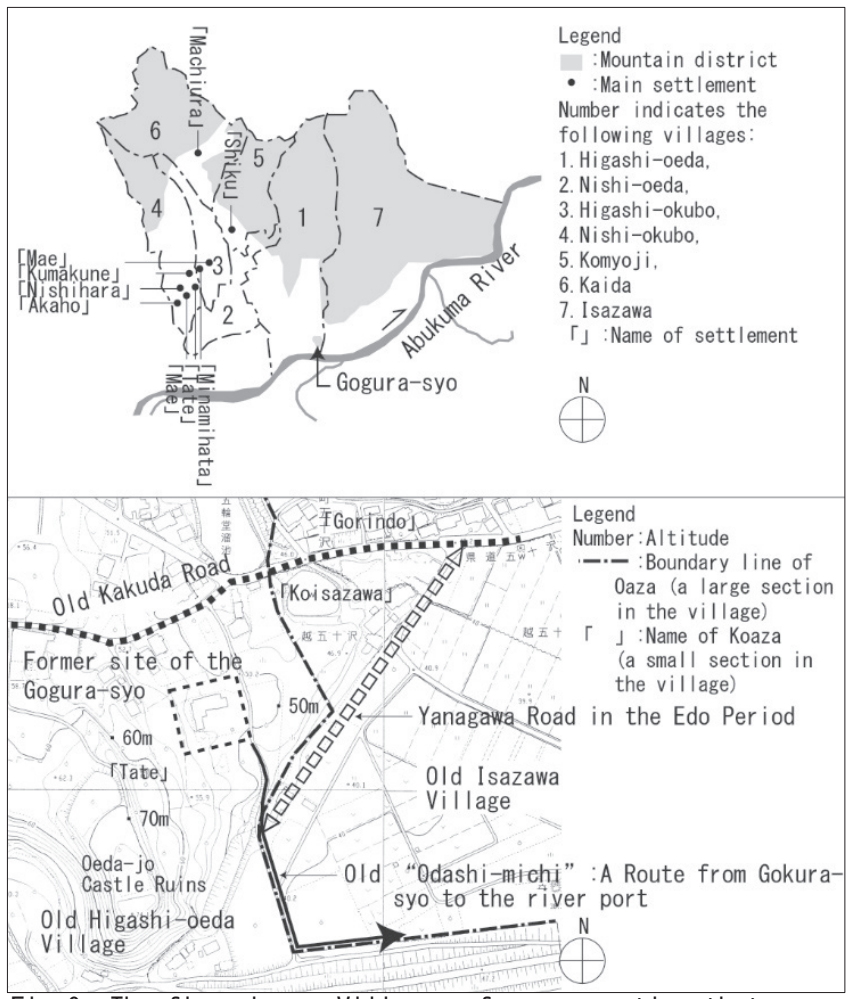

Fig. 9 The fig. above: Villages of a cooperative that concerned the Higashi-oeda Gogura-syo The fig. below: A map of Historic spot in the Higashi-oeda District Date City

Table2 The distance from Higashi-oeda village to each village

\begin{tabular}{|c|c|c|c|}
\hline \multirow{2}{*}{ Destination } & \multicolumn{3}{|c|}{ Distance } \\
\hline & 里 Ri & 町 Tyо & 間 Ken \\
\hline Fudaba*1 in Isazawa village & & 21 & 10 \\
\hline Fudaba in Nishi-0eda village & & 16 & 30 \\
\hline $\begin{array}{l}\text { Fudaba in Higashi-okubo Village } \\
\text { (古料 koryo*2) }\end{array}$ & & $\begin{array}{l}\text { A little more than } \\
20\end{array}$ & \\
\hline Fudaba in Kaida Village & 1 & 7 & \\
\hline
\end{tabular}

Table3 The distance from each village to the Gogura-syo

\begin{tabular}{|c|c|c|c|}
\hline \multirow{2}{*}{$\begin{array}{l}\text { Starting point: each } \\
\text { village }\end{array}$} & \multicolumn{3}{|c|}{ Distance } \\
\hline & 里 Ri & 町 Туо & $\begin{array}{c}\text { 間 } \\
\text { Ken }\end{array}$ \\
\hline Nishi-oeda & & A little more than 24 & \\
\hline $\begin{array}{l}\text { Higashi-okubo } \\
\text { (新料 shinryo*1) }\end{array}$ & & About 26 & \\
\hline Nishi-okubo & $\begin{array}{llll}A & \text { little more than } \\
1 & \end{array}$ & & \\
\hline
\end{tabular}
notes of table 2 
域に関係なく、多数の村が一棟を村の米高に応じて区分したものと 考えられる。つまり、長屋形式である。

\section{2 郷蔵}

\section{2.1 共通性}

藩政中期の 2 ケ村蔵組の渡利村、藩政中期以降の 9 ケ村もしくは 10 ケ村蔵組の桑折村の寄蔵（郷蔵所）や幕末期の 8 ケ村蔵組（東 大窪村を新古 2 ケ村とした場合）の東大枝村の郷蔵所の実態が知ら れた。桑折村の寄蔵や東大枝村の郷蔵所に共通寸る点は、第一に、 多くの蔵が村毎に棟を分けている点である（以後、「分棟形式」とす る)。第二に、敷地囲いの河岸側とその反対側へ向かって門が開かれ ている点である。相違点は、蔵々の配置である。桑折村の寄蔵に対 して東大枝村の郷蔵所の建物配置には規則性がない。Fig. 7 の敷地 内において 4 棟の蔵が北門側に、その他の蔵は南門側に寄せて配置 されている。1棟の御蔵が西端に配置されている。北門（Fig. 7 の a もしくはb) や南門（同 c) から見た場合、御蔵は敷地の奥に位置し ている。

一方、藩政中期の 2 ケ村蔵組の渡利河岸の寄蔵は、一棟を村毎に 区分けしていたことが考えられる。このような長屋形式の寄蔵は、 河岸までの道程が長いため留屋を設けた同時代の立子山村や御代田 村の寄蔵にも見られる注 54)。分棟形式と比較した場合これらは、蔵 組の村の数が少なく、村々の室の桁行は留屋同等であり注 ${ }^{55)}$ 、一棟 を共有した方が効率よかったと推察される。また、分布域も異なる。

以上、伊達郡の阿武隈川左岸においては、多数の村が 1 つの敷地 に各々蔵を設ける郷蔵所があり、このような建築方式は他の地域の 藩政中期の寄蔵や留屋と異なるものである。なお、ここで言う他の 地域は、上記した信夫郡の阿武隈川右岸（渡利河岸の寄蔵）や、伊 達郡の阿武隈川右岸小手郷（立子山村や御代田村の寄蔵）の地域で ある。

\section{2.2 空間構成手法}

本稿では、分棟形式の東大枝村郷蔵所に焦点を当て、その空間構 成手法を検討することにしたい。蔵組の西大䆶村に関する文久元年 （1861）「西大窪村指出明細帳」注 56) に、「一江戸御廻米者、東大枝 河岸二御蔵建置、毎年初納御触之節、津出し相納申候、」をありこ の郷蔵所は、幕末期においても寄蔵として用いられていたことが知 られる。なお、同書に「一御蔵場 土蔵式間半四間 穀入壱間式間 壱ヶ所」とあり、当時西大窪村に「御蔵場」があったが、その主た る用途は不明である。

第一に、貝田村と光明寺村の郷蔵は、北門寄りに位置している。 蔵組の村々の位置を比較すると、貝田村は、東大枝村から最も離れ ており $(\mathrm{Tab} 1 \mathrm{e} 2)$ 、現在、旧貝田村の「町裏」や旧光明寺村の「志久」 といった主たる集落は (Fig. 9 上) 、旧西大窪村や旧東大窪村の主た る集落より標高の高い場所に見られる注 57 。 藩政期当時、両村の年 貢米は、馬などに載せて天保 8 年（1837）の「奥州伊達郡東大枝村 絵図」に描かれる幹線道路（Fig. 6 の b) を通り、北門から運び入れ られたと考えられる。

第二に、五十沢村の郷蔵は、南門寄りに位置している。五十沢村 の村域は、阿武隈川に沿っており、蔵組の中では唯一、本郷蔵所か ら見て阿武隈川の下流側に位置する (Fig. 9 上)。Fig. 6 には、東大 枝村の町場から郷蔵所の北を通り、五十沢村へ至る幹線道路（同図 のb）が描かれている。また、藩政期の作の「伊達郡東根領内絵図」
注 58) には、東大枝村の渡船場から五十沢村へ至る道筋が描かれてい る。後者の道は、明治前期の文献に記される「梁川街道」であり注59)、 本郷蔵所付近において御出道に交わるものと考えられる (Fig. 9 下)。 五十沢村の場合、この道を用いれば、他の村域を通らずに南門から 本郷蔵所へ年貢米を運び入れることができた。

第三に、「東大枝御蔵」は、門から見て最も敷地奥、敷地の西端に 位置していた。城跡側の比較的安全な高い場所に設けられているも のの、年貢米の輸送距離が最も短い村であり、他村に配慮した配置 と言えよう。

第四に、東大窪村の郷蔵と、西大窪村の郷蔵は、庭を挟んで離し て配置されている。これらの村域は、郷蔵所から見て阿武隈川の上 流側に位置する (Fig. 9 上)。これらの村の年貢米も、前述の幹線道 路（Fig. 6 の b) を通って、北門から運び入れられたと考えられる。 隣接する 2 ケ村は、村から郷蔵所までの距離の差が少なく注 60 )

(Table3)、村名が似ているので、両村の年貢米の運び入れが重なる と、混雑や間違いが生じやすい。これを避けるために蔵同士を離し たと考えられる注 61 。規模の大きい長屋形式の留屋でも、村名が似 ている村同士は室を離していた注 ${ }^{62)}$ 。なお、東大䆶村における新料 の蔵と古料の蔵は、さらに離して配置されている。このことは、東 大枝村と西大枝村にも当てはまるだろう。

以上、東大枝村の郷蔵所の村々の蔵の配置は、地理的条件や納入 時の混雑を避けることに配慮されていたと考えられる。

\section{5. まとめ}

本研究は、近世期の信達地方阿武隈川沿いに設けられた郷蔵関連 施設に関して以下のことを明らかにした。

藩政中期の信達地方には、城米輸送のための留屋と寄蔵があった。 留屋は、村の郷蔵から河岸までの距離が長い場合、村々の組合（河 岸組）が設けた城米の留め置きを目的とした河岸の施設であった。 一方、寄蔵は、川沿いの村などに蔵組が設けた郷蔵所であった。

藩政中期の留屋の共通点は、桁行が村によって異なる比較的小規 模な室で構成されていることであり、その空間構成手法は一棟を 村々が米高に応じて区分する長屋形式であった。その建築の中には、 「雨屋」や小屋と呼ばれる比較的簡易な木造が含まれ注 ${ }^{63)}$ 、普請に は河岸組の村々が共同して当たっていた。一方、寄蔵は、分棟形式 と長屋形式があった。前者の実例として Fig. 4 の建築遺構が位置付 けられる。藩政後期になると、留屋は見られなくなるが、信夫郡の 天神河岸に、1 ケ村が設けた川岸御蔵が確認できた。伊達郡の阿武 隈川左岸の郷蔵所は、藩政中期の寄蔵を引き継ぐものであり、分棟 形式であった注 ${ }^{64)}$ 。その敷地囲いには門が河岸とその反対側へ向か って開かれていた。このように蔵組の村々の郷蔵を集めることで、 村々にとっては蔵守を共有できるメリットがある。また、幕府や蔵 組の役人にとっては城米の安定した津出しを図ることができた。東 大枝村の郷蔵所の空間構成手法は、村々の地理的条件一の配慮と、 納入時の混雑の回避に起因するものであった。

以上、藩政中期の信達地方の寄蔵や留屋は、村々が共同して城米 輸送を行うための仕組みの主体であり、その意識は幕末期の郷蔵所 に伝えられていたと考えられる。

今後も、村々に営まれた郷蔵所の空間構成について研究を進めて いきたいと考えている。桑折村の寄蔵における建物配置の要因や東 
大枝村の郷蔵所の変遷については、新たな史料の発見を待って検討 したい。

\section{謝辞}

2010 年、福島県国見町の郷土史家菊池利雄氏に河岸跡や寄蔵の建 築遺構をご案内いただき、参考文献を頂戴した。絵図史料の利用に ついて、伊達市教育委員会、桑折町教育委員会からご配慮をいただ いた。この機会を借りて御礼を申し上げる。

\section{参考文献}

1) A society to research the history of domain administration: Hanseiseiritsushi-no-sogokenkyu Yonezawahan (General Research about the establishment of the domain administration, Yonezawa Domain), Yoshikawa kobunkan, 1983

藩政史研究会：藩制成立史の総合研究 米沢藩, 吉川弘文館, 1983

2) Editorial board of "The Great Dictionary of National History" : Kokushi-daiziten(The Great Dictionary of National History), Vol. 3, Yoshikawa kobunkan, 1994

国史大辞典編集委員会：国史大辞典第 3 巻，吉川弘文館， 1994

3) Watanabe, N. : Kaido-to-suiun(Highway and Water transportation), Iwanami Japan History Course, Vol. 10, Iwanami Shoten, 1975 渡辺信夫：街道と水運，岩波講座日本歴史 10 , 岩波書店, 1975

4) Edited by Fukushima Pref. : Fukushimakenshi(History of Fukushima Pref. ), first half of Vol. 10, Fukushima Pref. , 1967 福島県編：福島県史第 10 巻上, 福島県, 1967

5) Kobayashi, H: Goguraseido-no-hensen(Transition of a tax system which used Gogura), Kobayashi, H, 1934

小林平左衛門：拫蔵制度の変遷，小林平左衛門， 1934

6) Edited by editorial board of "History of Hobara Town" : Hobaratyoshi (History of Hobara Town), Vol. 2, Hobara Town, 1983 保原町史編纂委員会編：保原町史第 2 巻, 保原町, 1983

7) Edited by editorial board of "History of Kawamata Town" : Kawamatatyoshi (History of Kawamata Town), Vol. 2, Kawamata Town, 1976

川俣町史編纂委員会編：川俣町史第 2 巻, 川俣町, 1976

8) Edited by editorial board of "History of Fukushima City" : Fukushimashishi (History of Fukushima City), Vol. 8, Educational Board of Fukushima City, 1968

福島市史編纂委員会編：福島市史第 8 巻, 福島市教育委員会, 1968

9) Yasuda, H. : Gojomaitsudashi-to-abukumagawa-no-syuun(Shipping the Gojomai from the port and Water transportation in the Abukuma River), Journal of the study of History in Fukushima Pref. , Vol. 49, pp. 128, 1987. 10 (in Japanese)

安田初雄: 御城米津出と阿武隈川の舟運, 福島史学研究, 第 49 号, pp. 128, 1987. 10

10) Takekawa, S: Abukumagawa-no-syuun (Water transportation in the Abukuma River), Rekisyun-fukushimabunko Vol. 61, Rekishishunjusha, 2005

竹川重雄：歴春ふくしま文庫 61 阿武隈川の舟運, 歴史春秋社, 2005

11) Tomiyama, H. : Fukushimaken-abukumasanmyakuchitai-no-gogura -nitsuite(About Gogura in the Abukuma Mountains of the Fukushima Pref. ) -study on the storehouse Part 7-, Architectural Institute of Japan Research Report, No. 58, pp. D29-D32, 1961. 6 (in Japanese) 12) Sagami, C. : Study on Spatial Structures of Okura-syo Owned by the Yanagawa Domain in the Edo Period, Journal of Architecture and Planning (Transactions of AIJ), Vol. 85, No. 771, pp. 1079-1088, 2020. 5 (in Japanese)

13) Sagami, C. : Study on Spatial Structures of Okura-syo Owned by the Hirosaki Domain in the Edo Period, Journal of Architecture and Planning (Transactions of AIJ), Vol. 83, No. 746, pp. 755-762, 2018. 4 (in Japanese)

14) Sagami, C.: Spatial Structure Characteristics of Okura-dokoro
Owned by the Morioka Domain Located on the Kitakami River in the Edo Period, Journal of Architecture and Planning (Transactions of AIJ), Vol. 75, No. 657, pp. 2693-2699, 2010. 11 (in japanese) 15) Sagami, C. : A Study on the Spatial Structures of Edo Period' s River Side Water Transportation Facilities Owned by Aizu Domain -In Case of Shiokawa Okura-tokoro-, Journal of Architecture and Planning (Transactions of AIJ), Vol. 75, No. 653, pp. 1721-1727, 2010. 7 (in japanese)

16) Sagami, C. : Spatial Structure of Mikura-yashiki Owned by the Yonezawa Domain Located on the Mogami River in the Edo Period, Journal of Architecture and Planning (Transactions of AIJ), Vol. 74, No. 641, pp. 1655-1660, 2009. 7 (in japanese)

17) Sagami, C. and Iibuchi, K. and Nagai, Y. : Okuraba in Settlements Formed in the Kitakami River Basin in Sendai Fief -Case Study on the Wegedorf-, Minzoku-kenchiku (Folk Architecture), No. 130, pp. 15-24, 2006. 11 (in japanese)

18) Sagami, C. : Spatial Structure of Gogura-syo Located in the Echigo Prpvince in the Edo Period, Journal of Architecture and Planning (Transactions of AIJ), Vol. 77, No. 675, pp. 1179-1186, 2012. 5 (in japanese)

19) Edited by educational board of Iino Town: Iinotyoshi-shiryo (History of Iino Town, source book), Vol. 2, Educational board of Iino Town, 1965 飯野町教育委員会編：飯野町史資料第 2 集，飯野町教育委員会，1965 20) Edited by educational board of Fukushima City:

Fukushimashi-bunkazaityosa-hokokusyo(Report on research of cultural property in Fukushima City), Vol. 39, Educational board of Fukushima City, 1998

\section{福島市教育委員会編：福島市文化財調査報告書第 39 集，福島市教育委員} 会, 1998

21) Edited by editorial board of "History of Kori Town" : Korityoshi (History of Kori Town), Vol. 6, Publishing board of “History of Kori Town”, 1992 桑折町史編纂委員会編：桑折町史第 6 巻，桑折町史出版委員会，1992 22) Edited by editorial board of "History of Ryozen Town" : Ryozentyoshi (History of Ryozen Town), Vol. 2, Ryozen Town, 1979 霊山町史編纂委員会編：霊山町史第 2 巻, 霊山町, 1979

23) Edited by Kunimi Town: Kunimityoshi (History of Kunimi Town), Vol. 2, Kunimi Town, 1973

国見町編：国見町史第 2 巻，国見町， 1973

24) Edited by editorial board of "History of Yanagawa Town" Yanagawatyoshi (History of Yanagawa Town), Vol. 7, Yanagawa Town, 1988

梁川町史編纂委員会編：梁川町史第 7 巻，梁川町， 1988

25) Edited by editorial board of "History of Yanagawa Town" : Yanagawatyoshi (History of Yanagawa Town), Vol. 10, Yanagawa Town, 1994

梁川町史編纂委員会編：梁川町史第 10 巻，梁川町，1994

26) Edited by editorial board of "History of Yanagawa Town" Yanagawatyoshi (History of Yanagawa Town), Vol. 6, Yanagawa Town, 1986

梁川町史編纂委員会編：梁川町史第 6 巻, 梁川町, 1986

27) Edited by Kunimi Town: Kunimityoshi-shiryososyo (History of Kunimi Town, source book), Vol. 3, Kunimi Town, 1976

国見町編：国見町史資料叢書第 3 集，国見町， 1976

28) Edited by Kunimi Town: Kunimityoshi (History of Kunimi Town),

Vol. 4, Kunimi Town, 1975

国見町編：国見町史第 4 巻，国見町， 1975

29) Edited by Fukushima Pref. : Fukushimakenshi(History of Fukushima Pref. ), Vol. 9, Fukushima Pref. , 1965 福島県編：福島県史第 9 巻，福島県， 1965

30) Edited by Nakagawa, E: Dategun-sonshi (History of villages in Date County), Vol. 2, Rekishitosyosha, 1980

中川英右編：伊達郡村誌第 2 巻, 歴史図書社, 1980

31) Edited by editorial board of "History of Kori Town" : 
Korityoshi (History of Kori Town), Vol. 1, Publishing board of “History of Kori Town” , 2002

桑折町史編纂委員会編：桑折町史第 1 巻, 桑折町史出版委員会, 2002 32) Edited by editorial board of "History of Yanagawa Town" : Yanagawatyoshi (History of Yanagawa Town), Vol. 2, Yanagawa Town, 1999

梁川町史編纂委員会編：梁川町史第 2 巻, 梁川町, 1999

33) Edited by Kunimi Town: Kunimityoshi (History of Kunimi Town), Vol. 1, Kunimi Town, 1977

国見町編：国見町史第 1 巻，国見町， 1977

34) Edited by editorial board of "History of Kori Town" : MedemiruKorityonorekishi (History of Kori Town, Collection of photographs and pictures), Publishing board of “History of Kori Town”, 1985 桑折町史編纂委員会編：目で見る桑折町の歴史, 桑折町史出版委員会, 1985

\section{注}

注 1) 文献 1), p. 337

注 2) 文献 2), p. 749

注 3) 文献 3), p. 320

注 4)「信達両郡御廻米御用秘書写」(文献 4), pp. 1131-1138 所収), 文政元年 （1818）宝暦 8 年（1758）の「渡辺十右衛門證文」から、城米を移出す る 14 ケ所の河岸が知られる。

注 5) 文献 5), pp. 1-84 本書に、藩政期の郷蔵が、室町時代を起源とすること や、租税制度に伴う郷蔵、備荒制度に伴う郷蔵、租税制度と備荒制度の両 方に用いられた郷蔵の 3 種類に分けられることが述べられている。

注 6)「万手鑑」（文献 7), pp. 305-310 所収）, 天明 8 年 (1788） 本書に、「一 御米納八、前々八五ヶ村 六ヶ村と最寄二蔵を建置相納置、津出仕候処、 近年八初納より村別二、阿武隈川通福嶋渡利河岸 天神河岸、下郷八中瀬 河岸 伏黒河岸江納申候、(後略)」とある。

注 7) 文献 10), pp. 77-92

注 8) 文献 10), pp. 86-87

注 9) 文献 19), pp. 12-13 所収 文献 19), p. 68 に、本書は元禄・宝永期（16881710）を中心に記録したものと記されている

また、「小手郷村々書上帳」前文のうち天神留屋の項（文献 19), p.9 所収） に、「一、武間半二六間内大窪村 一、武間半二六間半青木村、一、武間半 二六間立子山一、武間半二六間飯野 辰二月十六日」とある。後述する 立子山村の項と比べると、大窪村と青木村の栴行長さが異なっており、改 築があったことが知られる。

注 10) 文献 8), pp. 69-73 所収

注 11) 文献 8), pp. 54-61 所収

注 12) 文献 19), pp. 46-48 所収 また、留屋の内訳について、「訳 一、三間 上手戸 一、四間 小神 一、三間 鶴田 一、三間 在郷小綱木一、 四間 上小国 一、武間 大綱木一、三間 秋山一、六間 飯坂村一、 三間 東五十沢 一、四間 大波一、三間 松沢一、三間 町小綱木 一、四間 羽田 一、三間 西五十沢 一、拾四間納米入」とある。

注 13) 渡利河岸には、渡利村・大笹生村の寄蔵や小手郷村々の留屋があり、複 数の建物があった。後述する瀬上村にも, 所轄や領主毎に分けられた 3 棟 の留屋があり、寄蔵の観を呈していた。施設が立地する村のみがこれを「寄 蔵」と呼んでおり、本来の蔵組の寄蔵や河岸組の留屋とは意味が異なった と考えられる。

注 14) 渡利歴史研究会蔵, 文献 20), pp. 36-37 掲載。天保 7 年 (1836) の「渡利 村絵図」は複数あり、上図は、画家玉泉の作。各河岸の蔵の描写はFig. 2 と 同じ。

注 15) 個人蔵, 文献 20), p. 22 掲載, 文化 2 年（1805）写し

注 16) 福島県立図書館蔵

注 17) 所在不明。文献 10), p. 82 掲載。なお、文献 10)に所蔵先は記されてお らず、著者は 10 数年前に逝去。

注 18) 文献 8), pp. 126-136 所収

注 19) 文献 8), pp. 110-119 所収

注 20)福島市及び伊達市の国登録有形文化財に登録されている土蔵物件は全 て覆屋がない。

注 21）「乍恐以書付申上候御事」（文献 4), pp. 1139-1140 所収）, 宝暦 7 年 （1757） 本内村、鎌田村、北矢野目村、南矢野目村、丸子村の 5 ケ村が仮 河岸の設置を願い出ている。

「相定申一札之事」（文献 4), p. 1141 所収）, 安永 4 年（1775） 本内（鎌
田）河岸の河岸組に、上記 5 ヶ村に加えて、入江野村、井野目村、左場野 村、飯野村、平田村、冲中野村、高梨村、宮代村の 8 ケ村が加わっている。 注 22) 文献 6), pp. 256-267 所収

注 23)「富沢村明細差出帳控」(文献 6),pp. 287-296 所収), 天保 14 年 (1843) 本書に、「(前略) 下小国村当村伏黒川岸江御錠米津出仕候道筋江御座候」 とある。富沢村は、文化 11 年（1814）から幕末まで苅谷藩領であった。

注 24) 建築年は明らかでないが、仮に呼称のみが継承されたものとしても、規 模は 1 ケ村分の大きさであり、この建築遺構から藩政期の寄蔵の建物を見 て大過ないと考えられる。なお、寄蔵の呼称は藩政中期まで用いられたこ とを前述した。

注 25）「御蔵守伝記大略」（文献 21）, pp. 678-680 所収）,藩政後期 米沢藩領 時代の寛文 2 年 (1662)、御蔵所に御蔵守の先祖が居住した。

注 26) 前掲注 25)

注 27）「石母田村差出帳」（文献 23）, pp. 285-291 所収), 元禄 13 年（1700）, 本書に、「一鄉蔵之儀、当村二八無御座候、桑折村之寄蔵一入置、(後略)」 とある。

注 28) 後掲注 31) 参照。

注 29) 文献 21), pp. 733-741 所収

注 30）「南半田村明細帳」（文献 21）, pp. 749-757 所収), 宝暦 5 年 (1755) 本 書に、「一、鄉蔵之義者、当村二無御座候、桑折村寄蔵場二御座候、(後略)」 とある。

注 31）寛政 6 年（1794）の「桑折町絵図」（大聖寺蔵、文献 34）,pp. 58-59 掲 載）には、 2 棟の蔵と蔵とは異なる 1 棟の居宅が描かれている。北門から南 へ向かって庭であり、突き当りに居宅がある。2 棟の蔵はこの庭を挟んで妻 側を向けて向かい合っている。本図は、主な土地利用や町の景観を描くこ とに重点が置かれており、北門から伺える敷地内の様子を大まかに描いて いる。蔵の棟数は正確でないが、蔵の配置に関して Fig. 5 と同じ空間構成 が見て取れる。

注 32) 前掲注 25)

注 33) 前掲注 25） 本書に、「(前略) 近頃寛政之末、享和之始御銀山御置米 村々江御預ヶ二相成候二付、御廻米之分計り蔵組十ヶ村二而扶持方等相減 候」とある。なお、本書に蔵組の村々として、桑折村、万正寺村、谷地村、 南半田村、北半田村、泉田村、小坂村、鳥取村、内谷村、山崎村の 10 个村 が記されている。

注 34) 文献 19), pp. 39-40 所収

注 35) 文献 6), pp. 267-272 所収

注 36) 文献 22), pp. 411-423 所収

注 37) 文献 23), pp. 292-298 所収

注 38 ）東大枝村は、元禄 13 年（1700）に桑折藩領、延享 4 年（1747）に上野 篠塚藩領になったが、寛延元年（1748）以降は幕府領であった。但し、安永 4 年（1775）から寛政元年（1789）までの間は仙台藩預地になっている。 注 39) 文献 24), pp. 636-637 所収 注 40) 文献 24), pp. 26-33 所収

注 41) 伊達市教育委員会蔵

注 42) 文献 25), p. 1066

注 43)「明治二十年 地籍 二冊八内一 伊達郡東大枝村」, 福島県歴史資料 館蔵 本書の 82 番 (蔵敷)に、「廿二年二月廿三日 幸圃用二付全筆払下」 と加筆されている。

注 44)「信達両郡古来諸事留書」(文献 26), pp. 3-17 所収)，宝暦 5 年 (1755) 宝暦 3 年 (1753)、幕府は「囲粐制度」をとった。本書に、幕府領川俣付・ 大森付 (信夫郡) の村々の置粐蔵について、幕府代官所が新築を命じ、そ の入用は公儀より出ることが記されている。

注 45) 文献 9),p.9 安田は、江戸の浅草御蔵において納入手続が完了するま で、本途米及び、欠米の各村分を区別しておく必要があったと述べている。

注 46）「明細差出帳東大窪村之内新料ひかえ」（文献 27）, pp. 88-91 所収）, 天 保 8 年 (1837) 本書に、「一当村之義者上知、古料、新料と三ヶ料二分郷 二罷成申候、」とある。

注 47)「村誌 伊達郡高城村」(文献 28), pp. 673-678 所収), 明治 14 年 (1881) 注 48) 文献 29), pp. 742-751 所収

注 49) 前掲注 48)

注 50) 広島市立中央図書館蔵

注 51) 前掲注 12)

注 52) 3.2.6 節 梁川村などの蔵組の例であるが、他の幕府領においても同じ 事情であったことが推測される。

注 53) 文献 12), p. 1080

注 54) 前掲注 9)に、「一、鄉蔵 長廿弐間 横三間半 四ヶ村寄蔵 六間飯 
野・五間大窪・五間青木・六間立子山村」とあり、1 棟と見られる。 前掲注 34)に、「一、寄蔵 長十壱間横三間はり 九間二三間はり 右八小 嶋、手戸、上糠田、布川、御代田（ママ）六ヶ村」とあり、2 棟を 6 ケ村が 共有している。

注 55) 前掲注 9) の留屋と比較すると、飯野村と立子山村の桁行は同じである が、大窪村と青木村の桁行は 1 間ほど短い。なお、梁行は 1 間長い。

注 56) 文献 23), pp. 331-336 所収

注 57) 旧貝田村の字地「町裏」は、標高 $170 \mathrm{~m}$ 辺り、旧光明寺村の字地「志久」 は、標高 $85 \mathrm{~m}$ 辺りに見られる。一方、明治 14 年 (1881) の「村誌 伊達郡 大木戸村（旧西大窪村）」（文献 28）, pp. 669-673 所収）によると、人家 5 戸以上の字地は、「赤穂」、「前」、「館」、「西原」、「熊久根」であり、現在こ れらの字地の多くは、標高 $60 \mathrm{~m}$ 辺りに見られる。旧東大窪村に関する前掲 注 47)によると、人家 5 戸以上の字地は、「前」、「南畠」であり、現在これ らの字地は、標高 $70 \mathrm{~m}$ 辺りに見られる。

貝田村の町場は、奥州道中の宿駅であった。その他の字地は、新田では なく、古来の農村と推察される。従って、本書から幕末期の字地を見ても 大過ないと考えられる。

注 58) 徳川林政史研究所蔵

注 59）「村誌 伊達郡五十澤村」（文献 30), pp. 241-261 所収）, 明治 14 年 （1881） 本書の道路の条に、「梁川街道 西部五輪堂ノ東端二於テ角田街 道ヨリ岐シテ南シ折レテ越五十澤ノ南端二傍フテ西シ又折レテ南シ船場ノ 渡頭二至ル (後略)」と記されている。

注 60) 明和 9 年 (1772) の「西大枝村明細差出帳」（文献 23）, pp. 310-314 所 収）に「東大枝郷蔵所江武拾四丁余」、前掲注 46) 天保 8 年（1837）の「明 細差出帳東大窪村之内新料ひかえ」に「東大枝郷蔵迄廿六丁程」、前掲注 56) 文久元年（1861）の「西大窪村指出明細帳」に「東大枝村河岸御蔵迄壱里 余」と記されている。

注 61) 各村から東大枝村郷蔵所までの距離の差は、東大窪村 (新料) と西大窪 村との間よりも、西大枝村と東大窪村（新料）との間の方が少なく、後者 の 2 ヶ村の蔵は隣り合っている（Fig. 7)。しかし、東大窪村の蔵は 2 棟あ り、敷地の東端の方が新料の蔵であれば、西大枝村の蔵と隣り合うことは ない。他の村の明細帳は現存しない。

注 62) 前掲注 12） 本書は留屋の端から順に各室を記したものと考えられよ う。なお、本書の村々の室の並びに関して他に有効な根拠は見出せない。 「在郷小綱木」・「大綱木」・「町小綱木」や、「東五十沢」・「西五十沢」はそ れぞれ離して配置されている。

注 63）「山舟生村明細帳」（文献 24）,pp. 3-11 所収）, 享保 16 年（1731） 本 書に、梁川村の寄蔵と留小屋の普請における入用について記されている。 どちらにも「竹木八御立林二而被下」とあるが、寄蔵に関してのみ「御役 萱を以莫替仕候」とあり、敷地囲いの入用が記されているので、この留小 屋は茅莫屋根でなく、敷地囲いがなかったと思われる。

注 64) 文献 18), pp. 1180-1181 近世期における越後国の郷蔵所の実態が知ら れる事例のうち、寄蔵の形式は三島郡飯塚村の郷蔵所のみであった。この 蔵組は 3 ケ村で、それぞれ独立した蔵をもつ。蔵の大きさはまちまちであ る。越後国の郷蔵所の場合、計蔵と呼ばれる検査所が併設されるが、上記 の郷蔵所では村々が 1 棟の計蔵を共有した。

注 65) 文献 30), pp. 12-261 所収

\section{図版出典}

Fig. 1 筆者作製

Fig. 2 「奥州信夫郡福嶋領渡利村絵図」, 天保 7 年 (1836) , 福島県歴史資料 館蔵 本図は、村の土地利用を描くことを目的としているが、主な建物を 立体的に描いている点に特徴がある。

原図の写真に、記号、（）の文字を記入した。

Fig. 3 筆者作製 本文で検討した河岸組や蔵組の範囲を網掛けし、これと津 出しを行った河岸とを矢印で結んだ。

Fig. 4 筆者撮影 (2010 年 5 月 29 日)

Fig. 5 「奥州桑折之図」, 作製年不明, 中根忠之氏蔵 本図には、本丸などの曲 輪が描かれてあり、作製年代は桑折藩統治時代（元禄 13 年 $(1700)$-延享 4 年 (1747)) の可能性がある。但し、桑折藩は、城を設けておらず、陣屋 があった。城下町の町並み及びその付近の屋敷地等の土地が描かれている。 土地は、分割され、それぞれに長さが記されている。また、寄蔵などに「不 納」と記されていることから、検地に関係する絵図史料と見られる。建物 は、寄蔵の他に寺地にも描かれている。本図の目的は、イメージではなく、 土地等の実情を把握することにあったと考えられる。河岸は記されていな いが、寄蔵と阿武隈川を結ぶ道筋が見られる。
文献 31 ) 付録の複写物 (桑折町教育委員会の許可を得て使用)に、解読文字、 方位、（）の文字を記入した。

Fig. 6 「奥州伊達郡東大枝村絵図」, 天保 8 年 (1837) , 伊達市教育委員会蔵 本図は、土地利用の他に集落などの建物や樹木を丁寧に描くなど、景観に も視点が置かれている点に特徵がある。郷蔵所には 5 棟の建物が描かれて いる。しかし、天明 9 年（1789）の蔵組は既に 7 ヶ村であり、省略されて いる可能性が高い。しかしながら、郷蔵所と蔵組の村々や河岸とのつなが りが知られる貴重な史料である。

史料未整理のため、文献 32 ) 掲載のために撮影された写真をトレースし(一 部省略)、記号、凡例、方位、（）の文字を記入した。

Fig. 7 「東大枝区有文書 地積改正野取図面」, 明治 9 年（1876）, 所蔵先不 明 本図は、地積改正のために作製されたものであり、旧郷蔵所の敷地面 積も記されている。従って、寸法に注意して描かれたものと考えられる。 旧郷蔵所の敷地は、明治 22 年（1889）の払い下げ時は 82 番地であり（前 掲注 43) )、現在の公図の 82 番地 (7つに分筆) と地区における位置及び凡 その敷地形状が一致する。

文献 33) 掲載図をトレースし、記号を記入した。

Fig. 8 筆者作製 本稿で参照した史料から知られる留屋及び同じ用途の川岸 御蔵を、 1 間を $1 \mathrm{~mm}$ として描いた。

Fig. 9 上図 筆者作製 貝田村、光明寺村、西大枝村、東大枝村、五十沢村の名 は、現在も大字として用いられている。また、明治 9 年 (1876) に西大窪 村は大木戸村、東大窪村（各分郷合併後）は高城村に改称され、これらの 名も、現在の大字に用いられているので、現在の大字境をもとに作製した。 なお、明治 14 年 (1881）の「村誌」注 ${ }^{65}$ に各村の東西方向と南北方向の幅 員 (「直径」とある) が記されているが、貝田村と西大窪村の南北方向の幅 員は、本図の 4 分の 3 ほどである。しかし、郷蔵所から見た各村の方位や 村々の位置関係の検討に用いても大過ないと考える。

下図 伊達市都市計画図 (No. $10 \cdot 11$ 、平成 20 年 (2008) 測量、縮尺 2500 分 の 1) に郷蔵所跡、旧街道、御出道等を加筆、文字を記入した。郷蔵所跡に ついては、明治 9 年（1876）の「地積改正野取図面」（Fig. 7）に「舘八十 番」と記されている。一方、明治 22 年 (1889) の土地台帳規則の制定のた めに作製された地籍図及び、関係資料の「蔵敷」の地番は「八十二」であ り、明治前期に地番が整理、変更されたことが推測される。上記の地籍図、 旧公図、現状の地番から推定した。但し、敷地の各辺の長さは明らかでな いので、Fig. 7 や土地台帳規則関係資料に記されている「一反五畧一歩」の 面積を正方形として描いた。藩政期の梁川街道については、前掲注 59）「村 誌伊達郡五十澤村」の記述などをもとに推定した。御出道については、 Fig. 6 において東大枝村と五十沢村の境を通っており、これらの村名が現 在の大字名になっているので、現在の大字境に描いた。

本研究は、科研費（18K04551）の助成を受けたものである。 


\title{
SPATIAL STRUCTURES OF FACILITIES CONCERNING GOGURA THAT LOCATED ALONG THE
} ABUKUMA RIVER IN THE SHINTATSU REGION IN THE EDO PERIOD

\author{
Chikao SAGAMI*1 \\ ${ }^{1}$ Prof., Dept. of General Engineering, National Institute of Technology, Sendai College, Dr.Eng.
}

Chapter 1: This study draws attention to facilities concerning the gogura that were located along the Abukuma River in the Shintatsu region for the shipping of jomai to Edo. It aims to clarify the fact of their spatial structures based on valuable illustrations, mura-meisai-tyo (details of a village), and other historical sources. In the Mid-Edo period, there existed facilities called yose-gura and tome-ya along the Abukuma River in that region. The yose-gura were formed by gathering village gogura in one place. The rice stored in the yose-gura was taken to the riverside and loaded onto boats as jomai. The tome-ya were facilities for storing jomai by the riverside and were jointly set up by villages that were unable to set up a yosegura near the riverside. Both facilities were common sights in the Mid-Edo period. In the Late Edo period, each village would set up their own facilities by the riverside.

Chapter 2: This chapter discusses previous research and the process of this study. It is concerned with the facilities of 10 towns and villages along the Abukuma River, where the existence of buildings is attested in historical sources.

Chapter 3: This showed each facility's structure and building overviews for each town or village. The discussion on riverside facilities included the actual circumstances of the tome-ya on the right bank of the Abukuma River (Tenjin bank and Watari bank of Watari Village, Shinobu County as well as Nakaze Village, Date County) in the Mid-Edo period and of the "kawagishi-okura" on the Tenjin bank in the Late Edo period. Meanwhile, the discussion on gogura included the actual circumstances of the yose-gura in the Mid-Edo period (Watari bank and Kori Village, Date County on the left bank of the Abukuma River) and of the Higashi-oeda Village's gogura-syo during the last days of the Tokugawa Shogunate.

Chapter 4: The commonalities and spatial structural techniques of the various riverside facilities and the gogura were considered. The former tome-ya were likely a building which villages share according to the amount of rice regardless of area. That is, they were row houses. Some of these were simply wooden structures called amaya. The latter yose-gura of the Mid-Edo period had two case concerning the building method depending on size. First is to gather each village's gogura, it is called "bunto". Second is row house. The gogura-syo on the left bank of the Abukuma River in Date County were bunto that inherited the tradition of the yose-gura of the Mid-Edo period. The arrangement of buildings at the Higashi-oeda Village's gogura-syo during the last days of the Tokugawa Shogunate likely reflected the geographical conditions of each village to avoid congestion when delivering the rice.

Chapter 5: The conclusion. Yose-gura and tome-ya in the Shintatsu region during the Mid-Edo period were at the heart of a system where villages worked together to transport jomai, a practice that continued in the gogura-syo during the last days of the Tokugawa Shogunate. 